\title{
THE KINETIC PROFILE OF IRON DISSOLUTION FROM LATERITE ORE IN CHLORIC ACID SOLUTION
}

\author{
PROFIL KINETIKA PELARUTAN BESI DARI BIJIH LATERIT \\ DALAM LARUTAN ASAM KLORIDA
}

\author{
SOLIHIN ${ }^{1}$, PRATAMA ARINALDO ${ }^{2}$, NANDA S. DEWI ${ }^{2}$ and HARYADI PERMANA ${ }^{1}$ \\ ${ }^{1}$ Research Centre for Geotechnology - LIPI \\ Komplek LIPI, Jalan Sangkuriang Bandung, West Java, Indonesia \\ e-mail: solihin@lipi.go.id \\ ${ }^{2}$ Syarif Hidayatullah State Islamic University Department of Chemistry \\ Jl. Ciputat, Tangerang Selatan, Banten Provence, Indonesia
}

\begin{abstract}
Indonesia has large amount of laterite deposits located in Southeast Sulawesi. The laterite contains significant amount of iron. The ore has been processed through high temperature. The high temperature consumes a lot of energy and releases a lot of carbon dioxide. The low temperature of the process is simple and needs less energy. Leaching the ore is the important stage in low temperature which determines the recovery of valuable metal from the ore. This work observes the kinetic aspect of iron dissolution in the process based on the shrinking core model. The data of iron dissolution at temperature $30,50,70$ and $90^{\circ} \mathrm{C}$ are plotted into chemical reaction control and diffusion control equations. The result shows that at 30 and $50{ }^{\circ} \mathrm{C}$, the whole leaching process is controlled by the rate balance between chemical reaction and diffusion, whereas at 70 and $90{ }^{\circ} \mathrm{C}$, the reaction is controlled by diffusion.
\end{abstract}

Keywords: laterite, iron, hydrometallurgy, leaching, kinetic

\begin{abstract}
ABSTRAK
Indonesia memiliki deposit bijih laterit yang besar di Sulawesi Tenggara. Bijih tersebut mengandung besi dalam jumlah yang signifikan. Pengolahan bijih tersebut melalui proses temperatur tinggi. mengkonsumsi energi dan mengeluarkan emisi karbon dioksida dalam jumlah yang sangat besar. Di sisi lain, proses menggunakan temperatur rendah merupakan proses yang lebih sederhana dengan konsumsi energi yang jauh lebih rendah. Dalam proses ini pelindian bijih adalah tahapan yang paling penting karena menentukan perolehan logam dari bijih. Penelitian ini mengamati aspek kinetikpelarutan besi dari bijih laterit berbasis model shrinking core. Data dari pelarutan pada temperatur 30, 50, 70 dan $90{ }^{\circ} \mathrm{C}$ diplot terhadap persamaan terkendali reaksi kimia dan terkendali difusi. Hasil penelitian menunjukan bahwa pada temperatur 30 dan $50{ }^{\circ} \mathrm{C}$, keseluruhan reaksi pelindian dikendalikan oleh kesetimbangan reaksi kimia dan difusi, sedangkan pada temperatur 70 dan $90{ }^{\circ} \mathrm{C}$ proses pelindian dikendalikan oleh difusi.
\end{abstract}

Kata kunci: laterit, besi, hidrometalurgi, pelindian, kinetika

\section{INTRODUCTION}

Laterite ore contains mainly iron in the oxide form. The iron (Fe) is commonly used as a raw material in the fabrication of many products such as cars, trains, bicycle, kitchen stuff, building parts, weapons, etc.
The material can be obtained from its oxide mineral that contains iron element such as hematite $\left(\mathrm{Fe}_{2} \mathrm{O}_{3}\right)$, goethite $(\mathrm{FeOOH})$, magnetite $\left(\mathrm{Fe}_{3} \mathrm{O}_{4}\right)$, etc. In Indonesia, these oxide minerals can be found in laterite ore deposit. South East Sulawesi Province has been known as the region that has a huge 
amount of iron-nickel laterite ore deposit (Moe'tamar, 2007; van Leeuwen and Pieters, 2011). Some of high grade laterite in this area has been processed to produce ferronickel, a raw material in stainless steel production, through a high temperature (Nelson et al., 2007). The high temperature consumes a large amount of energy and produce a large amount of carbon dioxide. In order to produce a large amount of energy, a large amount of high quality coal and electricity are needed in the high temperature route of process (Solihin, 2015). Since the price of coal and electricity tends to rise, the feasibility of this kind of process will eventually decrease. Another alternative to process the laterite ore is the low temperature route of process. Such a process is quite simple, in which the laterite ore is dissolved in acid solution prior to the refining stage. Iron dissolution is a very important step; it determines the recovery of iron for the whole process (Solihin, Mubarok, et al. 2015). Nickel which is more valuable than iron within the laterite ore is obviously dissolved during the dissolution process. Based on the Eh-pH diagram of nickel and iron, the area of nickel ion stability is larger than that of iron, which means that nickel is easier to dissolve than iron (Takeno, 2005). Unfortunately, nickel oxide content in laterite is very much smaller than goethite substance. It makes the nickel oxide is physically trapped in the goethite (Butt and Cluzel, 2013). This fact indicates that nickel dissolution is very much affected by iron dissolution from goethite. Thus, the iron dissolution is more important factor to be evaluated than that of the nickel. Therefore, the aim of this research is to show iron dissolution from the laterite ore.

\section{THE BRIEF GEOLOGICAL REVIEW OF NICKEL LATERITE ORE}

The nickel ore of lateritic soil was formed from chemical weathering of olivine-rich peridotite rocks such as harzburgite and dunite. The peridotite rock, part of oceanic crust or upper mantle is widely distributed in Indonesia with Ophiolite Complex such as found in Ciletuh Basement Complex, West Java; Meratus Mountains, South Borneo, in the East and Southeast of Sulawesi Island (Kadarusman et al., 2004), Kabaena Island, Buton Island, West Timor Island (Ishikawa et al., 2007), East Halmahera Island, Obi Island, West Seram Island, Gebe Island, Gag Island, Waigeo Island, and in Papua Island that exposed in Nabire area, Central Highlands and Cyclops Mountains as shown in Figure 1 (Monnier et al., 1999; Sukamto, 2002; Permana, Girardeau, et al., 2005; Permana, Soeria-atmadja, et al., 2005). The peridotite rocks also present as tectonic slices that is found associated with Sumatran Fault (Northern Sumatra) or gathered in melange complexes in Simeuleu Island, Siberut Island, Lok Ulo Melange Complex, Central Java and Laut Island, South Kalimantan (Sukamto, 2002).

Nickel laterite or regolith was very weathered soil, rich in iron $(\mathrm{Fe})$ or nickel $(\mathrm{Ni})$ content, cobalt (Co) and rarely scandium (Sc) (Butt and Cluzel, 2013). Regolith is formed by continuous chemical and mechanical weathering of serpentinized peridotite or peridotite rocks (Marsh and Anderson, 2011) expose in warm, and wet tropical environments (Ashcroft, 2013; Butt and Cluzel, 2013). Rocks weathered rocks formed 5 layers, from below to surface: fresh or un-weathered peridotite bedrocks, weathered bedrock known as saprolites, rich clay of saprolite layer and oxide alteration of the clay layer, hydrous Mg-silicates of limonite layer and iron cup or ferricrust (Marsh and Anderson, 2011; Ashcroft, 2013). Other factors that control lateritic nickel soils formation are tectonic processes, climates, groundwater conditions or drainage pattern and morphological forms (Marsh and Anderson, 2011; Ashcroft, 2013; Butt and Cluzel, 2013). During weathering process, the $\mathrm{Ni}$ is concentrated in goethite and / or smectite minerals in any layer of weathered peridotite (Marsh and Anderson, 2011) and it is increasingly richer in residual soil associated with $\mathrm{Mg}$ and $\mathrm{Si}$ losses due to dissolution (Butt and Cluzel, 2013). Although peridotite-serpentinite rocks are poor in nickel content (up to about $0.3 \%$ ), the weathering and enrichment processes of peridotite-serpentininized rocks slowly raised nickel content up to about $5 \%$ because dissolve of other elements (Ashcroft, 2013). 


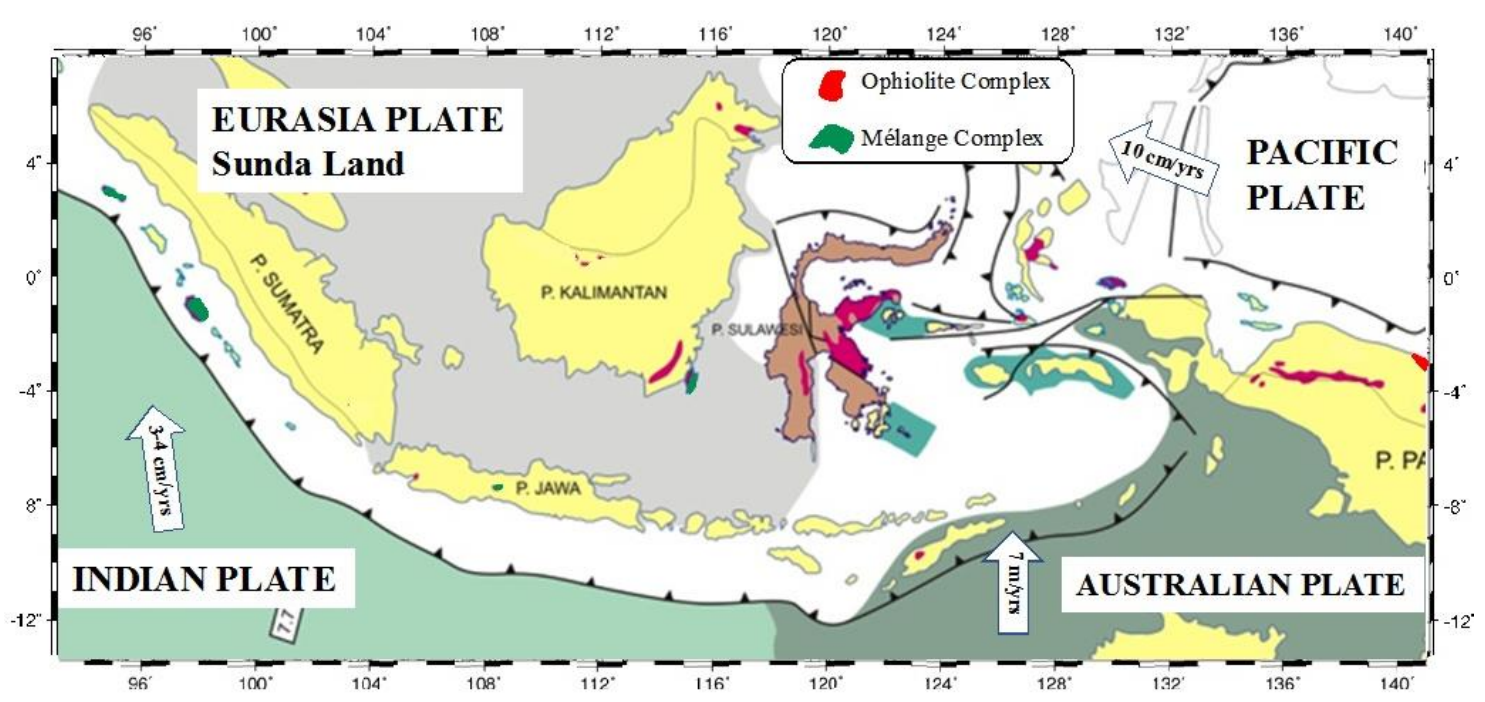

Figure 1. Distribution map of peridotite-serpentinite parent rocks in Ophiolitic Complex dan Melange Complex in Indonesia. Redrawn and slightly modified from Sukamto (2002);

Monnier et al. (1999); Permana, Girardeau, et al. (2005); Permana, Soeria-atmadja, et al. (2005)

\section{METHODOLOGY}

Laterite ore was obtained from a mining site in South East Sulawesi Province. The ore was dried in the oven at $100{ }^{\circ} \mathrm{C}$ to remove the moisture prior to grinding and milling. The equipment to grind and mill the ore are jaw crusher and ball mill, respectively. The size of dried, ground, and milled laterite ore is 100 mesh (150 micron). The hydrochloric acid solution was obtained from Merck. The solution is diluted to obtain optimum acid concentration that equals to $4 \mathrm{M}$. The dissolution experiment was conducted in a beaker glass that was filled with $150 \mathrm{ml}$ acid solution. 15 gram of ground and milled laterite ore was added into solution and it was stirred at $250 \mathrm{rpm}$ for 4 hours. The selection of stirring speed and leaching time is based on the preliminary experiment (Solihin et al., 2013) in which it showed that this stirring speed is adequate for achieving the laminar flow of pulp and this leaching time is enough to observe the kinetic profile of iron dissolution. The effect of temperature in the dissolution process was studied at temperature $30,50,70$ and $90{ }^{\circ} \mathrm{C}$. The kinetic of dissolution was studied before the iron extraction percentage reaches $100 \%$. The type of mineral in the laterite ore and its composition was analyzed through X-Ray Diffraction using CuK- $\alpha$ radiation (Shimadzu XRD-7000) and XRF (Thermo Niton XL3t), respectively. The percentage of iron in the residue of dissolution process was analyzed through XRF (Thermo Niton XL3t).

\section{RESULT AND DISCUSSION}

The XRD pattern of dried laterite ore is shown in Figure 2. The ore consists of goethite $(\mathrm{FeOOH})$ and antigorite $\left(\mathrm{Mg}_{24} \mathrm{Si}_{1} 7(\mathrm{OH})_{31} \mathrm{O}_{42.5}\right)$. Goethite and antigorite was formed at certain place in Indonesia, as the result of weathering of serpentine rock in under continuing rainforest climates.

Element composition of laterite ore is shown in Table 1. Weight percentage of iron in the ore is $30.111 \%$. Other elements in the Table 1 are magnesium, silicon, nickel and other minor elements. Iron in laterite ore from Indonesia is usually in the range of 10-46\% (Lee, Kim and Oh, 2005). The amount of iron in laterite from Philippine, Australia and China, depend on its location in each country, is quite similar with that from Indonesia (Li et al., 2009; Ma et al., 2013; MacCarthy et al., 2015). Nickel and other minor elements are trapped in the matrix of goethite and antigorite (Butt and Cluzel, 2013). The previous work (Solihin, 2015) that mapped the elements in laterite using SEM equipment also proves that nickel and the minor elements are really trapped in the matrix of goethite and antigorite. 
The dissolution profile of iron from laterite ore in hydrochloric acid at temperature 30 , 50,70 and $90{ }^{\circ} \mathrm{C}$ is shown in Figure 3. At 30 ${ }^{\circ} \mathrm{C}$, the dissolution rate seems to take place slowly. The percentage of iron extracted from laterite after being leached for 250 minutes is less than $40 \%$. The increasing of temperature seems to give significant effect to the increase of iron extraction. After being leached at 50, 70 and $90{ }^{\circ} \mathrm{C}$ for long time, around $100 \%$ of iron has been dissolved in acid solution. Although iron in the ore can be dissolved almost entirely at 50, 70 and 90 ${ }^{\circ} \mathrm{C}$, the dissolution profile of iron at each temperature are different. At $50^{\circ} \mathrm{C}$, the rate of iron dissolution is very much less than those at 70 and $90^{\circ} \mathrm{C}$. At $50^{\circ} \mathrm{C}$, it takes 250 minutes to achieve $100 \%$ extraction of iron, whereas for those at 70 and $90{ }^{\circ} \mathrm{C}$, it takes only 125 and 25 minutes, respectively. The profile of metal dissolution from laterite ore in acid solution at temperature $50{ }^{\circ} \mathrm{C}$ or higher usually follows the similar pattern, in which the extraction percentage of metals increase drastically as the leaching time increase, until it reaches a turning curve where the dissolution of the metals becomes very much slower than before (Rice, 2016).

Table 1. Elemental composition of laterite ore

\begin{tabular}{cc}
\hline Elements & \% Weight \\
\hline $\mathrm{Fe}$ & 30,111 \\
$\mathrm{Ni}$ & 3,297 \\
$\mathrm{Cr}$ & 0,803 \\
$\mathrm{Mn}$ & 0,556 \\
$\mathrm{Ag}$ & 0,161 \\
$\mathrm{Co}$ & 0,149 \\
$\mathrm{Cd}$ & 0,114 \\
$\mathrm{Pd}$ & 0,061 \\
$\mathrm{Zn}$ & 0,039 \\
$\mathrm{Mo}$ & 0,003 \\
$\mathrm{~Pb}$ & 0,004 \\
Others (Mg, Si, O, etc) & 64,702 \\
\hline
\end{tabular}

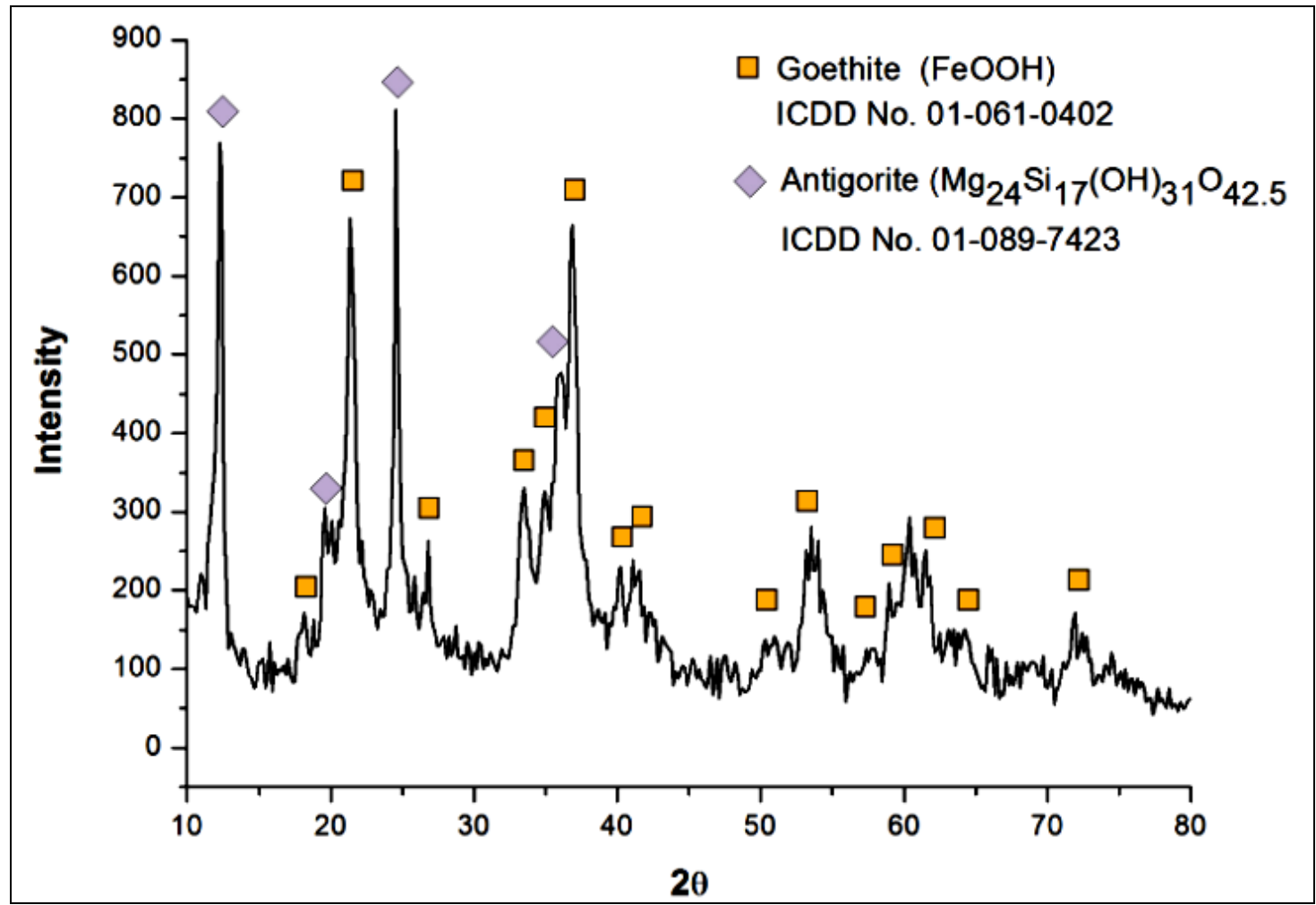

Figure 2. XRD pattern of dried laterite ore 


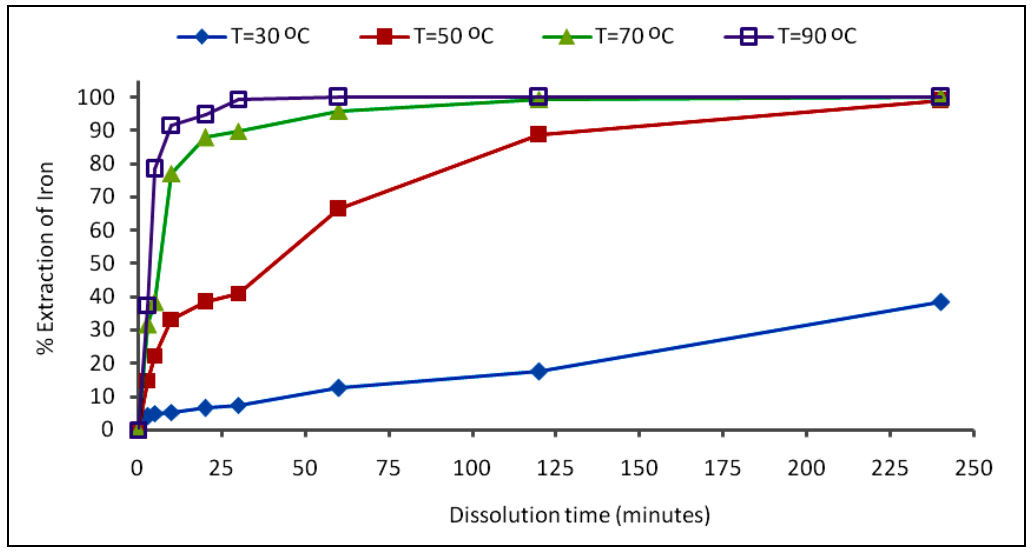

Figure 3. Dissolution profile of iron from laterite ore at $30,50,70$ and $90{ }^{\circ} \mathrm{C}$ and concentration of chloric acid $4 \mathrm{M}$

Generally, in heterogeneous chemical reaction, there are two mechanisms that control the whole process. First mechanism is the chemical reaction that takes place at the interface of solid (ore) and liquid (acid solution). The order of a chemical reaction and chemical reaction constant definitely influence this mechanism, which result a chemical reaction to be slow or fast. The second mechanism is the diffusion of reactant or reaction product through a diffusion layer. The diffusion of a matter through a diffusion layer is very much influenced by the diffusion constant and the length of diffusion layer. The difference of speed in each mechanism determines the dominant mechanism that controls the whole process. The slower mechanism will control the speed of the whole process (Habashi, 1999). Leaching of laterite is the dissolution of metals from oxide or silicate mineral particles. The model that can be used to approach the process mechanism of ore leaching is shrinking core model. This model has been used to reveal the kinetic profile of certain leaching process. Through this model, the mechanism that controls a process can be revealed by plotting the metal dissolution data into two equations that represents each mechanism (Habashi, 1999; Olanipekun, 2000; Mbaya, Ramakokovhu and Thubakgale, 2013).

$1-(1-\alpha)^{1 / 3}=k_{1} \mathrm{t}$

$1-2 / 3 \alpha-(1-\alpha)^{2 / 3}=k_{2} t$

Where $\alpha=$ fraction of iron being dissolved in the acid

$\mathrm{k}=$ constant

$\mathrm{t}=$ dissolution time
Equation (1) and (2) represent the chemical reaction and the diffusion the control process, respectively. The result of the data fitting into equation (1) is shown in Figure 4. The data of iron dissolution at $30{ }^{\circ} \mathrm{C}$ seems to fit with equation (1). The trend line of this data has Determination Coefficient $\left(R^{2}\right)$ equals to 0.947 . Meanwhile, the plotting of the $50{ }^{\circ} \mathrm{C}$ iron dissolution data results in the linear trend line that has value of $R^{2}$ equals to 0.899 , which means that the data is less match with equation (1). In contrast, the plotting of data of iron dissolution at 70 and $90{ }^{\circ} \mathrm{C}$ are obviously very unfit with equation (1). Therefore, the linear trend line of those plotted data cannot be drawn in the Figure.

Figure 5 presents the plotting of iron dissolution data at $30{ }^{\circ} \mathrm{C}$ into equation (2). The plotting of this data into equation (2) shows that the data fits with linear trend line with $R^{2}$ equal to 0.988 . The plotting of the data of iron dissolution at $30^{\circ} \mathrm{C}$ into equation (1) and equation (2) results in two linear trend lines that both have relatively almost similar $R^{2}$. It means that at $30^{\circ} \mathrm{C}$ chemical reaction rate is in balance with diffusion rate. The similar case with the plotting of data of iron dissolution at $30^{\circ} \mathrm{C}$ is the plotting of those at $50^{\circ} \mathrm{C}$, which is shown in Figure 6. The value of $R^{2}$ resulted from the fitting of those data into equation (1) and equations (2) are almost the same. It means that at $50{ }^{\circ} \mathrm{C}$ there is balance between chemical reaction rate and diffusion rate. The type of process that has balance mechanism between chemical reaction and diffusion is called intermediate control process. 


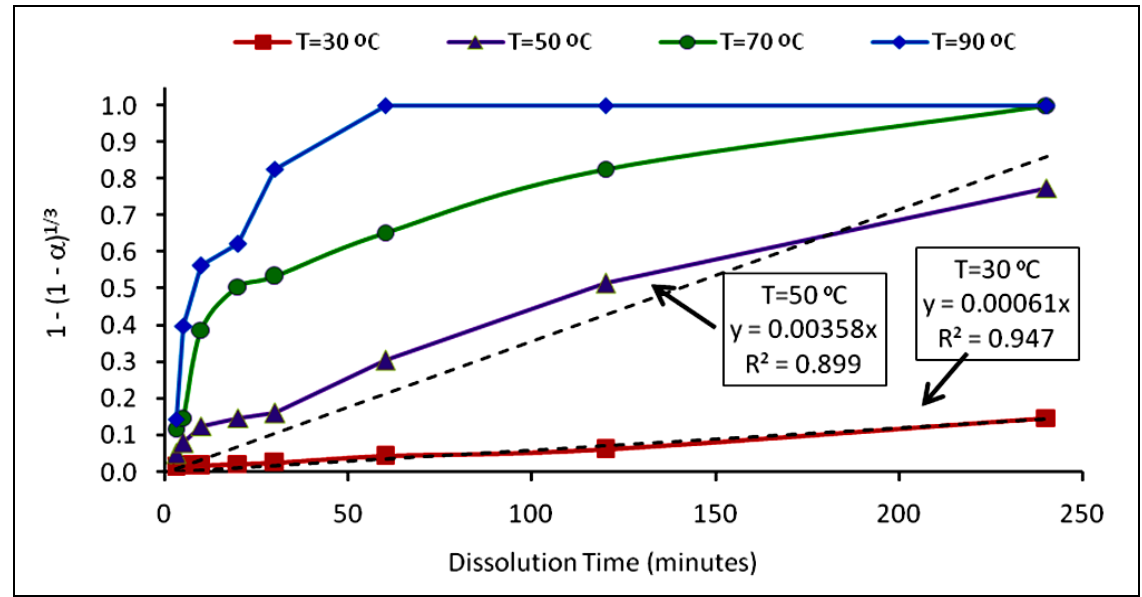

Figure 4. The plotting of the data of iron dissolution at $30,50,70$ and $90{ }^{\circ} \mathrm{C}$ into equation $1-(1-\alpha)^{1 / 3}=k_{1} t$

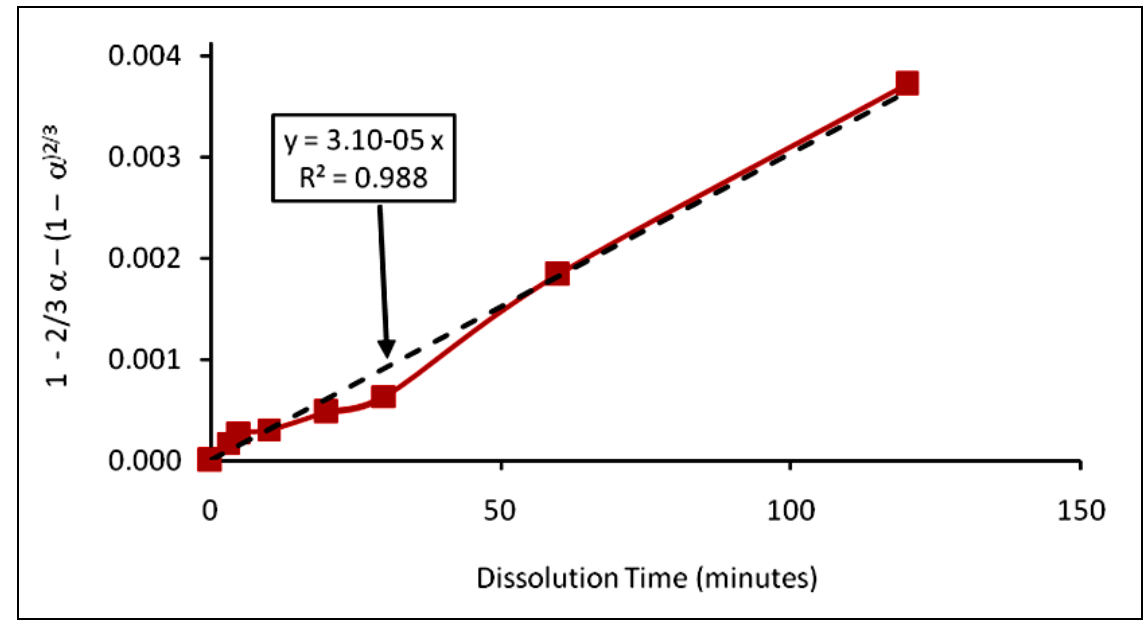

Figure 5. The plotting of the data of iron dissolution at $30^{\circ} \mathrm{C}$ into equation $1-2 / 3 \alpha-(1-\alpha)^{2 / 3}=k_{2} t$

The plotting of the data of iron dissolution at 70 and $90{ }^{\circ} \mathrm{C}$ into equation (2) is shown in Figure 7. Both data plotting result in the linear trend lines that have $R^{2}$ equal to 0.938 and 0.922 , for the data of iron dissolution at 70 and $90{ }^{\circ} \mathrm{C}$, respectively. On the other hand, this result is different from the plotting of the same data into equation (1), in which the plotting of those data do not produce linear trend line. In the other word, at 70 and $90^{\circ} \mathrm{C}$, the whole process is controlled by diffusion.

The iron dissolution reaction becomes more rapid as temperature is increased, as shown previously in Figure 2. Therefore, it is quite obvious that this reaction is an endothermic reaction. The rate of reaction in this type of reaction increases with the increase temperature. As previously explained, it is found through the plotting of iron dissolution data that at 30 and $50{ }^{\circ} \mathrm{C}$, the rate of chemical reaction is in balance with the rate of diffusion. The increasing of process temperature increases the rate of chemical reaction. The previous figure (Figure 1) clearly shows that the rate of chemical reaction at 70 and $90^{\circ} \mathrm{C}$ drastically increases so that the rate of chemical reaction is significantly higher than the rate of diffusion. At this stage, the availability of reactants that is needed by chemical reaction depends on the rate diffusion of ions from bulk solution of acid towards interface of solid-liquid, t where the chemical reaction takes place. In the other words, at these temperatures the whole process is controlled by diffusion. 


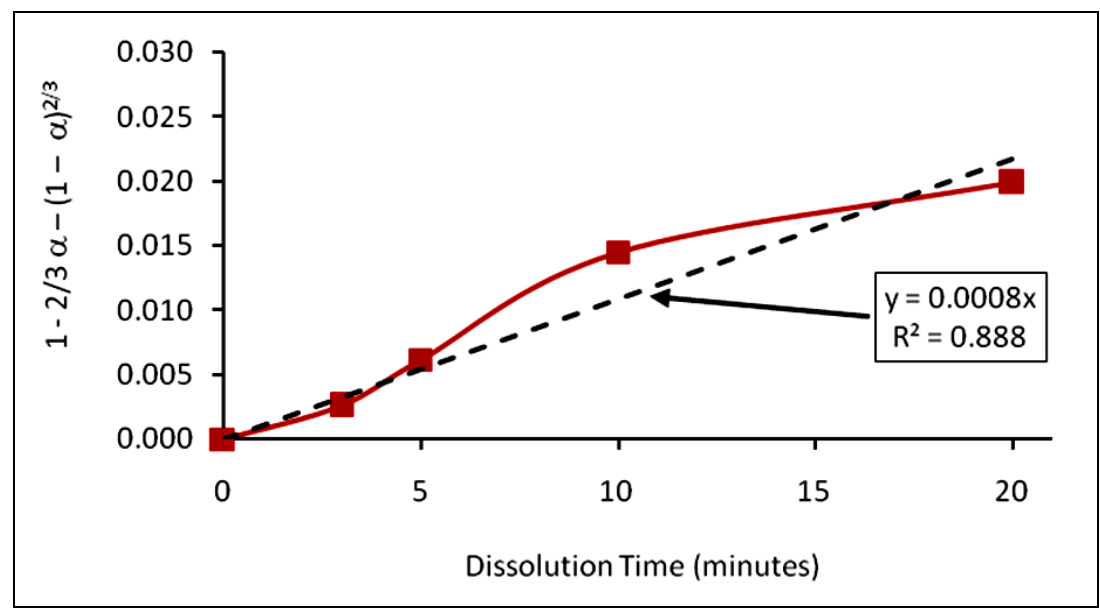

Figure 6. The plotting of the data of iron dissolution at $50{ }^{\circ} \mathrm{C}$ into equation $1-2 / 3 \alpha-(1-\alpha)^{2 / 3}=k_{2} t$

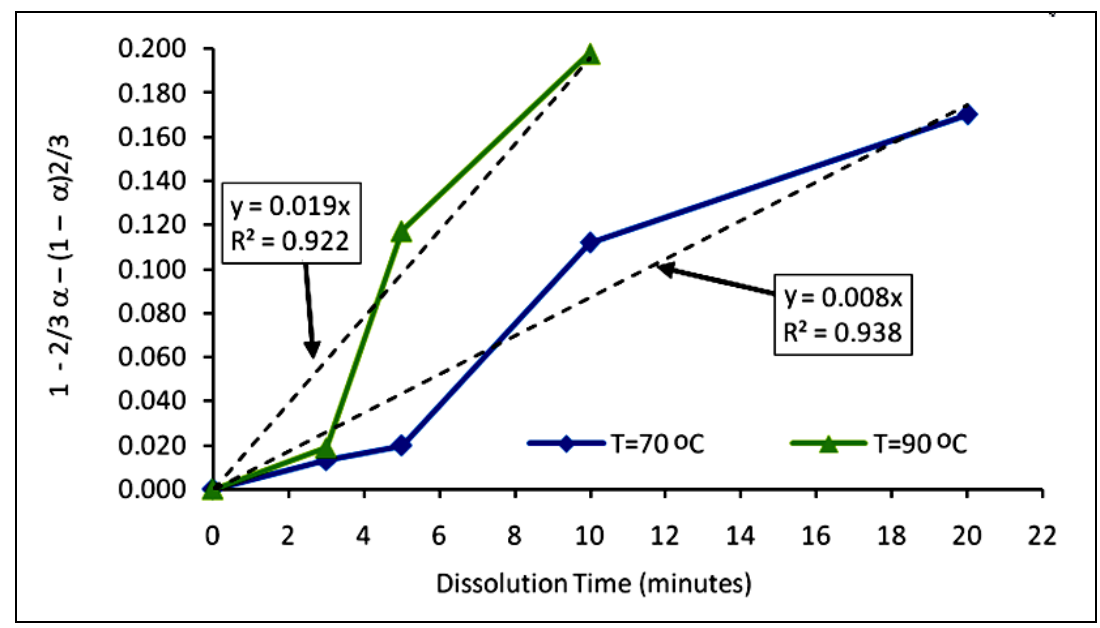

Figure 7. The plotting of the data of iron dissolution at 70 and $90{ }^{\circ} \mathrm{C}$ into equation $1-2 / 3 \alpha-(1-\alpha)^{2 / 3}=k_{2} t$

\section{CONCLUSION}

Laterite ore from South East Sulawesi contains goethite $(\mathrm{FeOOH})$ and antigorite $\left(\mathrm{Mg}_{24} \mathrm{Si}_{17}(\mathrm{OH})_{31} \mathrm{O}_{42.5}\right)$ mineral. This ore can be processed through leaching, which is an important stage in low temperature of route process. The leaching of this ore leads to the dissolution of components in the ore including iron. The dissolution of iron at temperature 30 and $50{ }^{\circ} \mathrm{C}$ is controlled by the rate balance of chemical reaction at the interface of solid-liquid and the diffusion of reactants for chemical reaction, whereas at 70 and $90{ }^{\circ} \mathrm{C}$ the whole process is controlled by diffusion of reactants of towards interface of solid-liquid.

\section{ACKNOWLEDGEMENT}

The authors would like to express our gratitude to The National Innovation System Research (Insinas), Ministry of Science, Technology and Higher Education for funding this research. We also would like to thanks to Antam Tbk for providing lateritic ore.

\section{REFERENCE}

Ashcroft, G. (2013) Nickel laterites: The world's largest source of nickel, Geology for Investorsestor. Available at: https://www.geologyforinvestors.com/nic kel-laterites/ (Accessed: 2 August 2018). 
Butt, C. R. M. and Cluzel, D. (2013) 'Nickel laterite ore deposits: Weathered serpentinites', Elements, 9(2), pp. 123128. doi: 10.2113/gselements.9.2.123.

Habashi, F. (1999) Kinetics of metallurgical processes. 1st Ed. Canada: Metallurgie Extractive Quebec.

Ishikawa, A., Kaneko, Y., Kadarusman, A. and Ota, T. (2007) 'Multiple generations of forearc mafic-ultramafic rocks in the Timor-Tanimbar ophiolite, eastern Indonesia', Gondwana Research, 11(12), pp. 200-217. doi: 10.1016/j.gr.2006.04.007.

Kadarusman, A., Miyashita, S., Maruyama, S. Parkinson, C. D. and Ishikawa, A. (2004) 'Petrology, geochemistry and paleogeographic reconstruction of the East Sulawesi Ophiolite, Indonesia', Tectonophysics, 392(1-4), pp. 55-83. doi: 10.1016/j.tecto.2004.04.008.

Lee, H. Y., Kim, S. G. and Oh, J. K. (2005) 'Electrochemical leaching of nickel from low-grade laterites', Hydrometallurgy, 77(3-4), pp. 263-268. doi: 10.1016/j.hydromet.2004.11.011.

van Leeuwen, T. M. and Pieters, P. E. (2011) 'Mineral deposits of Sulawesi', in Proceedings of the Sulawesi Mineral Resources 2011 SEMINAR MGEI-IAGI. Manado, pp. 1-109. doi: 10.13140/2.1.3843.2322.

Li, J., Li, X., Hu, Q., Wang, Z., Zhou, Y., Zheng, J., Liu, W. and Li, L. (2009) 'Effect of pre-roasting on leaching of laterite', Hydrometallurgy, 99(1-2), pp. 84-88. doi: 10.1016/j.hydromet.2009.07.006.

Ma, B., Wang, C., Yang, W., Chen, Y. and Yang, B. (2013) 'Comprehensive utilization of Philippine laterite ore, part 1: Design of technical route and classification of the initial ore based on mineralogical analysis', International Journal of Mineral Processing, 124, pp. 42-49. doi: 10.1016/j.minpro.2013.08.003.

MacCarthy, J., Nosrati, A., Skinner, W. and Addai-Mensah, J. (2015) 'Acid leaching and rheological behaviour of a siliceous goethitic nickel laterite ore: Influence of particle size and temperature', Minerals Engineering, 77, pp. 52-63. doi: 10.1016/j.mineng.2014.12.031.

Marsh, E. E. and Anderson, E. D. (2011) Ni-Co laterite deposits. 2011th-1259th edn.
Reston: U.S. Geological Survey. doi: 10.3133/ofr20111259.

Mbaya, R. K. K., Ramakokovhu, M. M. and Thubakgale, C. K. (2013) 'Atmospheric pressure leaching application for the recovery of copper and nickel from lowgrade sources', in The Southern African Institute of Mining and Metallurgy (Base Metals Conference 2013). Johannesburg: The Southern African Institute of Mining and Metallurgy, pp. 255-268.

Moe'tamar (2007) 'Inventarisasi endapan nikel di Kabupaten Konawe, Provinsi Sulawesi Tenggara', in Prosiding Pemaparan Hasil Kegiatan Lapangan dan Non Lapangan. Bandung: Pusat Sumber Daya Geologi, pp. 1-14. Available at: http://psdg.geologi.esdm.go.id/kolokium 2007/LOGAM/Logam_InventarisasiNickel_Konawe_SULT̄RA.pdf.

Monnier, C., Girardeau, J., Pubellier, M., Polvé, M., Permana, H. and Bellon, H. (1999) 'Petrology and geochemistry of the Cyclops ophiolites (Irian Jaya, East Indonesia): Consequences for the Cenozoic evolution of the north Australian margin', Mineralogy and Petrology, 65(1-2), pp. 1-28. doi: 10.1007/BF01161574.

Nelson, L. R., Geldenhuis, J. M. A., Miraza, T., Badrujaman, T., Hidyat, A. T., Jauhari, I., Stober, F. A., Voermann, N., Wasmund, B. O. and Jahnsen, E. J. M. (2007) 'Role of operational support in ramp-up of the FeNi-II furnace at PT Antam in Pomalaa', in International Conference on Innovations in the Ferro Alloy Industry (IFACON XI). New Delhi: Macmillan India, pp. 798-813.

Olanipekun, E. O. (2000) 'Kinetics of leaching laterite', International Journal of Mineral Processing, 60(1), pp. 9-14. doi: 10.1016/S0301-7516(99)00067-8.

Permana, H., Girardeau, J., Pubellier, M., Soeriaatmadja, R. and Monnier, C. (2005) 'Emplacement mechanism of the Cyclops ophiolite, Western Papua (Indonesia)', Majalah Geologi Indonesia, 20(2), pp. 103-115.

Permana, H., Soeria-atmadja, R., Girardeau, J., Pubellier, M., Monnier, C. and Bellon, $\mathrm{H}$. (2005) 'Weyland ophiolite of Nabire district, Western Papua, Eastern Indonesia: Origin and tectonic consequences', Majalah Geologi Indonesia, 20(2), pp. 90-102. 
The Kinetic Profile of Iron Dissolution from Laterite Ore in Chloric Acid Solution, Solihin et al.

Rice, N. M. (2016) 'A hydrochloric acid process for nickeliferous laterites', Minerals Engineering, 88, pp. 28-52. doi: 10.1016/j.mineng.2015.09.017.

Solihin, Mubarok, M. Z., Hapid, A. and Firdiyono, F. (2013) 'Percobaan proses leaching dan bioleaching pada bijih nikel kadar rendah Sulawesi', in Prosiding Seminar Metalurgi dan Material, pp. 95-99.

Solihin (2015) 'Synthesis of nickel containing pig iron (NCPI) by using limonite type of lateritic ore from South East Sulawesi', Riset Geologi dan Pertambangan, 25(1), pp. 31-35. doi: 10.14203/risetgeotam2015.v25.183.

Sukamto, R. (2002) 'Peta batuan ofiolit dan bancuh. Skala 1:10.000. 000'. Bandung: Pusat Survey Geologi, p. 1. Available at: https://psg.bgl.esdm.go.id/pameran/inde x.php?kategori=atlas\&halaman $=$ ofiolitbancuh\&title=Peta Batuan Ofiolit dan Bancuh.

Takeno, N. (2005) Atlas of Eh-pH diagrams: Intercomparison of thermodynamic databases. Tokyo. Available at: https://www.gsj.jp/data/openfile/no0419/ openfile419e.pdf. 
